\title{
Identification of Varroa mites (Acari: Varroidae) infesting Apis cerana and Apis mellifera in China
}

\author{
Ting ZHOU ${ }^{\mathrm{a}, \mathrm{c}, \mathrm{d}}$, Denis L. ANDERSON ${ }^{\mathrm{b}}$, Zachary Y. HUANG ${ }^{\mathrm{a}, \mathrm{c} *}$, \\ Shuangxiu HUANG ${ }^{\mathrm{c}}$, Jun $\mathrm{YAO}^{\mathrm{c}}$, Tan $\mathrm{KEN}^{\mathrm{e}}$, Qingwen ZHANG ${ }^{\mathrm{a}}$ \\ a Department of Entomology, China Agricultural University, Beijing 100094, China \\ ${ }^{\mathrm{b}}$ CSIRO Entomology, PO Box 1700, Canberra, ACT 2601, Australia \\ ${ }^{c}$ Department of Entomology, Michigan State University, East Lansing, MI 48824, USA \\ ${ }^{\mathrm{d}}$ Institute of Apicultural Research, Chinese Academy of Agricultural Sciences, Beijing 100093, China \\ e Eastern Bee Research Institute, Yunnan Agricultural University, Heilongtan, 650201, Kunming, China
}

(Received 8 September 2003; revised 19 April 2004; accepted 22 April 2004)

\begin{abstract}
A total of 24 Varroa mite samples were collected from A. mellifera and A. cerana colonies in 17 Provinces in China and subjected to DNA or restriction enzyme analyses. All Varroa mites from A. mellifera were identified as the Korean genotype of Varroa destructor Anderson and Trueman, confirming earlier finding that $V$. jacobsoni is not present in China, and a single genotype of Varroa is infecting the $A$. mellifera bees. Mites collected from A. cerana colonies at 2 locations in Guangdong Province were the China genotype of $V$. destructor. Mites collected from A. cerana colonies in 3 apiaries at Dayao County, Yunnan Province, and from 5 colonies at Mongzi County, Yunnan Province, were a new genotype, which was named the China 2 genotype of $V$. destructor. Mites collected from $A$. cerana colonies in 4 apiaries at Xishuangbanna, Yunnan Province, were the Vietnam genotype of V. destructor. These results should help future mite control and bee quarantine efforts in China.
\end{abstract}

Apis mellifera / Apis cerana / China 2 genotype of Varroa destructor / Varroa spp. / population genetics

\section{INTRODUCTION}

Information gathered during the past five years has revolutionised our understanding of Varroa mite taxonomy, genetic diversity, host-relationships and epidemiology (Delaplane, 2001). As it currently stands, there are four distinct species of Varroa; Varroa jacobsoni Oudemans, V. destructor Anderson and Trueman, $V$. underwoodi Delfinado-Baker and Aggarwal and $V$. rindereri De Guzman and DelfinadoBaker. The taxonomic status of three other Varroa genotypes has yet to be resolved (Anderson $\&$ Trueman, 2000). Each of these species and genotypes have been found to be natural ectoparasites on Asian honey bee species; $V$. jacobsoni on Apis cerana Fabricius mostly in India, southern mainland Asia and South-East Asia (Oudemans, 1904; Anderson \& Trueman, 2000; Anderson, 2002; Warrit and Smith, unpublished data), $V$. destructor on $A$. cerana mostly in the western and northern regions of mainland Asia (Anderson \& Trueman, 2000; Anderson, unpublished data), $V$. underwoodi on $A$. cerana throughout Asia (Delfinado-Baker \& Aggarwal, 1987; Woo, 1992; Anderson et al., 1997), V. rindereri on A. koschevnikovi v. Buttel-Reepen in Borneo (De Guzman \& Delfinado-Baker,

\footnotetext{
* Corresponding author: bees@msu.edu
} 
1996; Koeniger et al., 2002) and the three unresolved genotypes on A. cerana in the Philippines (Anderson \& Trueman, 2000).

The level of genetic variation among $V$. underwoodi, $V$. rindereri and the three unresolved Philippine genotypes has yet to be determined. However, a great deal of genetic variation has been reported among $V$. jacobsoni and $V$. destructor infesting Asian bees. To date, 15 different genotypes (or haplotypes - mites with distinct mtDNA CO-I gene sequences) of $V$. jacobsoni and eight of $V$. destructor have been reported, each only found on a specific geographic population of an Asian bee and each therefore named after the location (usually a country or island) from which it was first discovered on its natural Asian bee host (Anderson, 2000; Anderson \& Trueman, 2000; Anderson, unpublished data; Warrit and Smith, unpublished data). Hence, the Borneo genotype of $V$. jacobsoni was first discovered on A. cerana in Borneo in the 1990's by Anderson and Trueman (2000), while the Borneo 2 genotype was found in Borneo some time later by Koeniger et al. (2002). All known genotypes of V. jacobsoni and $V$. destructor are listed in Table I.

Even though much genetic variation has been found in $V$. jacobsoni and $V$. destructor, each genotype of these species show great consistency in the way it reproduces on its particular bee host. To reproduce, the adult female mites enter drone (male) and worker (sterile female) bee brood cells just prior to the cells being capped, preferring drone cells far more than worker cells. They then proceed to produce offspring on the drone but not on the worker brood. This inability to reproduce on worker brood is mostly responsible for rendering the mites relatively harmless to their natural host's colonies, because the adult worker bees, which perform most of the myriad of diverse colony tasks, such as collecting food and feeding young, remain largely undamaged during their developmental phase. On the other hand, drones that have been infested with, and damaged by, reproducing mites as brood, develop into behaviourally impaired adults. This however is not catastrophic to bee colonies, because drones, whose sole task is to mate with new queens, are produced by the colonies only when needed and usually in large quantities, much of which escapes parasitism by mites (Koeniger et al.,
Table I. Details of all known genotypes of $V$. jacobsoni (VJ) and V. destructor (VD). These genotypes exist naturally on specific populations of A. cerana in Asia and have been named after the location (country or island) in which they were first discovered on A. cerana.

\begin{tabular}{|c|c|c|}
\hline $\begin{array}{l}\text { Varroa species } \\
\text { (genotype) }\end{array}$ & $\begin{array}{c}\text { Genbank } \\
\text { accession } \\
\text { number }\end{array}$ & Reference \\
\hline $\mathrm{VJ}$ (Ambon) & AF106908 & $\begin{array}{c}\text { Anderson \& Trueman } \\
(2000)\end{array}$ \\
\hline VJ (Bali) & AF106909 & $\begin{array}{c}\text { Anderson \& Trueman } \\
\qquad(2000)\end{array}$ \\
\hline VJ (Borneo) & AF106907 & $\begin{array}{c}\text { Anderson \& Trueman } \\
\qquad(2000)\end{array}$ \\
\hline VJ (Borneo 2) & AY037890 & Koeniger et al. (2002) \\
\hline VJ (Flores) & AF106902 & $\begin{array}{c}\text { Anderson \& Trueman } \\
\qquad(2000)\end{array}$ \\
\hline VJ (India) & NA & $\begin{array}{c}\text { Anderson } \\
\text { (unpublished data) }\end{array}$ \\
\hline VJ (Java) & AF106910 & $\begin{array}{c}\text { Anderson \& Trueman } \\
\qquad(2000)\end{array}$ \\
\hline VJ (Laos) & NA & $\begin{array}{c}\text { Anderson } \\
\text { (unpublished data) }\end{array}$ \\
\hline VJ (Lombok) & AF106904 & $\begin{array}{c}\text { Anderson \& Trueman } \\
(2000)\end{array}$ \\
\hline VJ (Malaysia) & AF106906 & $\begin{array}{c}\text { Anderson \& Trueman } \\
(2000)\end{array}$ \\
\hline $\begin{array}{l}\text { VJ (North } \\
\text { Thailand 1) }\end{array}$ & NA & Warrit \& Smith (2004) \\
\hline $\begin{array}{l}\text { VJ (North } \\
\text { Thailand 2) }\end{array}$ & NA & Warrit \& Smith (2004) \\
\hline VJ (Sumatra) & AF106905 & $\begin{array}{c}\text { Anderson \& Trueman } \\
\qquad(2000)\end{array}$ \\
\hline VJ (Sumbawa) & AF106903 & $\begin{array}{l}\text { Anderson \& Trueman } \\
\qquad(2000)\end{array}$ \\
\hline VJ (Samui 1) & NA & Warrit \& Smith (2004) \\
\hline VD (China) & AF106900 & $\begin{array}{c}\text { Anderson \& Trueman } \\
\qquad(2000)\end{array}$ \\
\hline VD (China 2) & AY372063 & Current study \\
\hline VD (Japan) & AF106897 & $\begin{array}{l}\text { Anderson \& Trueman } \\
\qquad(2000)\end{array}$ \\
\hline VD (Korea) & AF106899 & $\begin{array}{c}\text { Anderson \& Trueman } \\
\qquad(2000)\end{array}$ \\
\hline VD (Nepal) & AF106898 & $\begin{array}{c}\text { Anderson \& Trueman } \\
\qquad(2000)\end{array}$ \\
\hline VD (Pakistan) & NA & $\begin{array}{c}\text { Anderson } \\
\text { (unpublished data) }\end{array}$ \\
\hline $\begin{array}{l}\text { VD (Sri } \\
\text { Lanka)* }\end{array}$ & AF106896 & $\begin{array}{l}\text { Anderson \& Trueman } \\
\qquad(2000)\end{array}$ \\
\hline VD (Vietnam) & AF106901 & $\begin{array}{l}\text { Anderson \& Trueman } \\
\qquad(2000)\end{array}$ \\
\hline
\end{tabular}

* Tentative member of VD (pending further data). NA: accession number not available. 
1981; Koeniger et al., 1983; Anderson, 1994; Rath, 1999; Anderson, 2000).

Only two Varroa genotypes from the large pool of genotypes present on Asian bees have been found capable of utilizing the European honey bee (A. mellifera L.) as an alternative host, following the introduction of this bee into Asia during the early 1900's. These are the Korea and Japan genotypes of $V$. destructor, so-called because they are natural parasites of A. cerana in Korea and Japan respectively (until recently the Japan mite was referred to as the Japan/Thailand genotype, but now is known simply as the Japan genotype). On their newlyfound bee host, the Korea and Japan genotypes become capable of reproducing on both drone and worker broods, a trait which has led to their current status as the most serious pests ever of A. mellifera. Of the two genotypes, the Korea genotype is the most common, being found on A. mellifera almost worldwide (Anderson \& Trueman, 2000; Garrido et al., 2003), even recently on A. mellifera in New Zealand (Zhang, 2000).

In China the identity of Varroa mites infesting $A$. cerana and $A$. mellifera has been poorly studied. This is despite the fact that Varroa mites were first noticed in China about 1957 (Chen, 1993) and that some of the first Varroa mites collected from A. mellifera came from China (Akratanakul \& Burgett, 1975). Initially, the mites detected on A. mellifera in China were thought to be $V$. jacobsoni, but Anderson and Trueman (2000) showed that $V$. jacobsoni was a species-complex and worldwide, only the Korea or Japan genotypes of $V$. destructor were causing damage to A. mellifera. Anderson and Trueman (2000) also found that mites collected from A. mellifera in China in 1996 were the Korea genotype of $V$. destructor, while other Varroa mites collected from A. cerana in Guangdong Province (Guangzhou) at the same time were a unique genotype, the China genotype of $V$. destructor. The pilot study by Anderson and Trueman (2000) not only suggested that the mites infesting A. mellifera and A. cerana in China were different but that they might also be genetically isolated from one another. The current study was carried out to clarify the incidence and taxonomic status of mites infesting A. cerana and A. mellifera in China.

\section{MATERIALS AND METHODS}

\subsection{Collection of bees and mites in China}

Samples of adult female Varroa mites were collected from hived A. mellifera and A. cerana colonies from the locations described in Table II and shown in Figure 1. In all hived A. cerana colonies and in most of the hived A. mellifera colonies, mites were collected live from the bodies of adult worker or drone bees or from capped worker or drone brood cells. However, in some hived A. mellifera colonies (samples 1-4, 9, 16, and 20), mites were also collected from the hive bottom boards within 24 hours following the placement of plastic strips impregnated with acaricide between brood frames.

Mites collected from live bees, brood cells and the bottom boards of hives were placed into small labelled glass vials containing $70 \%$ alcohol and transported to CSIRO Entomology laboratories in Canberra, Australia, where they were immediately stored at $-20^{\circ} \mathrm{C}$ until needed for DNA analyses.

We surveyed many colonies for Varroa mites in A. cerana colonies. In Hebei Province outside Beijing, we examined 200 capped drone and 200 worker cells in five colonies; in Hubei Province, we examined 2500 capped drone and 2500 worker cells in five $A$. cerana apiaries; and in Fuzhou City and Nanjing County in Fujian Province, the main A. cerana beekeeping districts of China, we examined 11000 capped drone cells and 8000 capped worker cells among 268 colonies. However, we failed to find $\mathrm{Var}$ roa mites at these locations in A. cerana. All mite samples on A. cerana were found in South China, mostly in Yunnan Province and some in Guangdong Province. In general Varroa mites caused much damage to A. mellifera colonies but few beekeepers observed their presence on A. cerana.

\subsection{Identification of mites}

The identities of Varroa mites collected from 17 of the 24 locations described in Table II and shown in Figure 1 were determined after they were removed from storage, washed twice in $70 \%$ alcohol, dried, their DNA extracted and parts of the mtDNA amplified by PCR and sequenced, and the sequences compared with known sequences of other Varroa mites following the methods described by Anderson and Fuchs (1998) and Anderson et al. (1998). The identities of mites from the remaining seven locations (all collected from A. mellifera colonies) were determined by restriction enzyme analyses. These latter analyses were also carried out on varying numbers of mites from each of the 24 locations to confirm whether their mtDNA sequences were invariant 
Table II. Details of the Varroa mite samples examined and their identity (genotype), based on mtDNA sequences and restriction enzyme analyses.

\begin{tabular}{|c|c|c|c|c|c|}
\hline $\begin{array}{l}\text { Sample } \\
\text { No. }\end{array}$ & Collection Sites ${ }^{1}$ & $\begin{array}{c}\text { Bee } \operatorname{Host}^{2} \text { (No. } \\
\text { of colonies/ } \\
\text { apiaries sampled) }\end{array}$ & $\begin{array}{l}\text { Sampling } \\
\text { Dates: } \\
\text { Month/ } \\
\text { Year }\end{array}$ & $\begin{array}{l}\text { No. of mites } \\
\text { sequenced /exa- } \\
\text { mined by } \mathrm{RE}^{3}\end{array}$ & Genotype $^{4}$ \\
\hline 1 & Yuci, Shanxi Prov. & $\operatorname{Am}(10 / 2)$ & $6,11 / 2001$ & $2 / 5$ & VD (Korea) \\
\hline 2 & $\begin{array}{l}\text { Nanjin, Xuzhou, Liuhe Co., Jiangsu } \\
\text { Prov. }\end{array}$ & $\operatorname{Am}(43 / 3)$ & $6,7,12 / 2001$ & $2 / 8$ & VD (Korea) \\
\hline 3 & Fuzhou, Nanjing Co., Fujian Prov. & $\operatorname{Am}(18 / 2)$ & $4,11 / 2001$ & $0 / 9$ & VD (Korea) \\
\hline 4 & $\begin{array}{l}\text { Fengman, Lishu Co., Changchun, Jilin } \\
\text { Prov. }\end{array}$ & $\operatorname{Am}(50 / 3)$ & $\begin{array}{c}9 / 2000 \\
5,11 / 2001\end{array}$ & $2 / 9$ & VD (Korea) \\
\hline 5 & Chifeng, Inner Mongolia & $\operatorname{Am}(20 / 1)$ & $9 / 2000$ & $0 / 3$ & VD (Korea) \\
\hline 6 & Xishuangbann, Yunnan Prov. & $\operatorname{Am}(5 / 1)$ & $5 / 2001$ & $0 / 2$ & VD (Korea) \\
\hline 7 & Xishuangbann, Yunnan Prov. & Ac $(4 / 1)$ & $5 / 2001$ & $2 / 2$ & VD (Vietnam) \\
\hline 8 & Institute of Apic Res., Beijing & $\operatorname{Am}(4 / 4)$ & $8 / 2000$ & $0 / 10$ & VD (Korea) \\
\hline 9 & $\begin{array}{l}\text { Hangzhou, Yiwu, Dongyang Co., } \\
\text { Zhejiang Prov. }\end{array}$ & $\operatorname{Am}(47 / 3)$ & $7,11 / 2001$ & $0 / 8$ & VD (Korea) \\
\hline 10 & Huangshan, Anhui Prov. & $\operatorname{Am}(5 / 1)$ & $7 / 2001$ & $2 / 3$ & VD (Korea) \\
\hline 11 & Ji'an Co., Jiangxi Prov. & $\operatorname{Am}(7 / 1)$ & $7 / 2001$ & $3 / 4$ & VD (Korea) \\
\hline 12 & Heilongjiang Prov. & $\operatorname{Am}(12 / 1)$ & $9 / 2001$ & $3 / 3$ & VD (Korea) \\
\hline 13 & Guiyang, Guizhou Prov. & $\operatorname{Am}(23 / 1)$ & $9 / 2001$ & $2 / 4$ & VD (Korea) \\
\hline 14 & Mianzhu Co., Sichuan Prov. & $\operatorname{Am}(21 / 1)$ & $9 / 2001$ & $3 / 2$ & VD (Korea) \\
\hline 15 & Zhuhai, Guangdong Prov. & Ac $(17 / 1)$ & $11 / 2001$ & $3 / 3$ & VD (China) \\
\hline 16 & Gangu Co., Gansu Prov. & $\operatorname{Am}(7 / 1)$ & $11 / 2001$ & $3 / 4$ & VD (Korea) \\
\hline 17 & Zhongshan, Guangdong Prov. & $\operatorname{Am}(15 / 1)$ & $11 / 2001$ & $0 / 3$ & VD (Korea) \\
\hline 18 & Dayao Co., Yunnan Prov. & Ac $(97 / 3)$ & $4 / 2002$ & $6 / 6$ & VD (China 2) \\
\hline 19 & Xishuangbanna, Yunnan Prov. & Ac $(67 / 3)$ & $4,5 / 2002$ & $6 / 10$ & VD (Vietnam) \\
\hline 20 & Yuanjiang, Hunan Prov. & $\operatorname{Am}(5 / 1)$ & $1 / 2002$ & $0 / 5$ & VD (Korea) \\
\hline 21 & Xinjiang Autonomous Region. & $\operatorname{Am}(7 / 1)$ & $6 / 2002$ & $2 / 4$ & VD (Korea) \\
\hline 22 & Zhongshan, Guangdong Prov. & Ac $(3 / 1)$ & $4 / 2002$ & $3 / 4$ & VD (China) \\
\hline 23 & Mongzi Co., Yunnan Prov. & $\operatorname{Ac}(5 / 1)$ & $5 / 2002$ & $10 / 25$ & VD (China 2) \\
\hline 24 & Mongzi Co., Yunnan Prov. & $\operatorname{Am}(2 / 1)$ & $5 / 2002$ & $4 / 20$ & VD (Korea) \\
\hline
\end{tabular}

${ }^{1}$ Co. = County, which is rural. If a place is not followed by Co., it designates the name of a city or town. Prov. = Province.

${ }^{2} \mathrm{Am}=$ Apis mellifera $; \mathrm{Ac}=$ Apis cerana .

${ }^{3} \mathrm{RE}=$ Restriction enzyme analyses.

${ }^{4} \mathrm{VD}=$ Varroa destructor (genotype is in parentheses). 


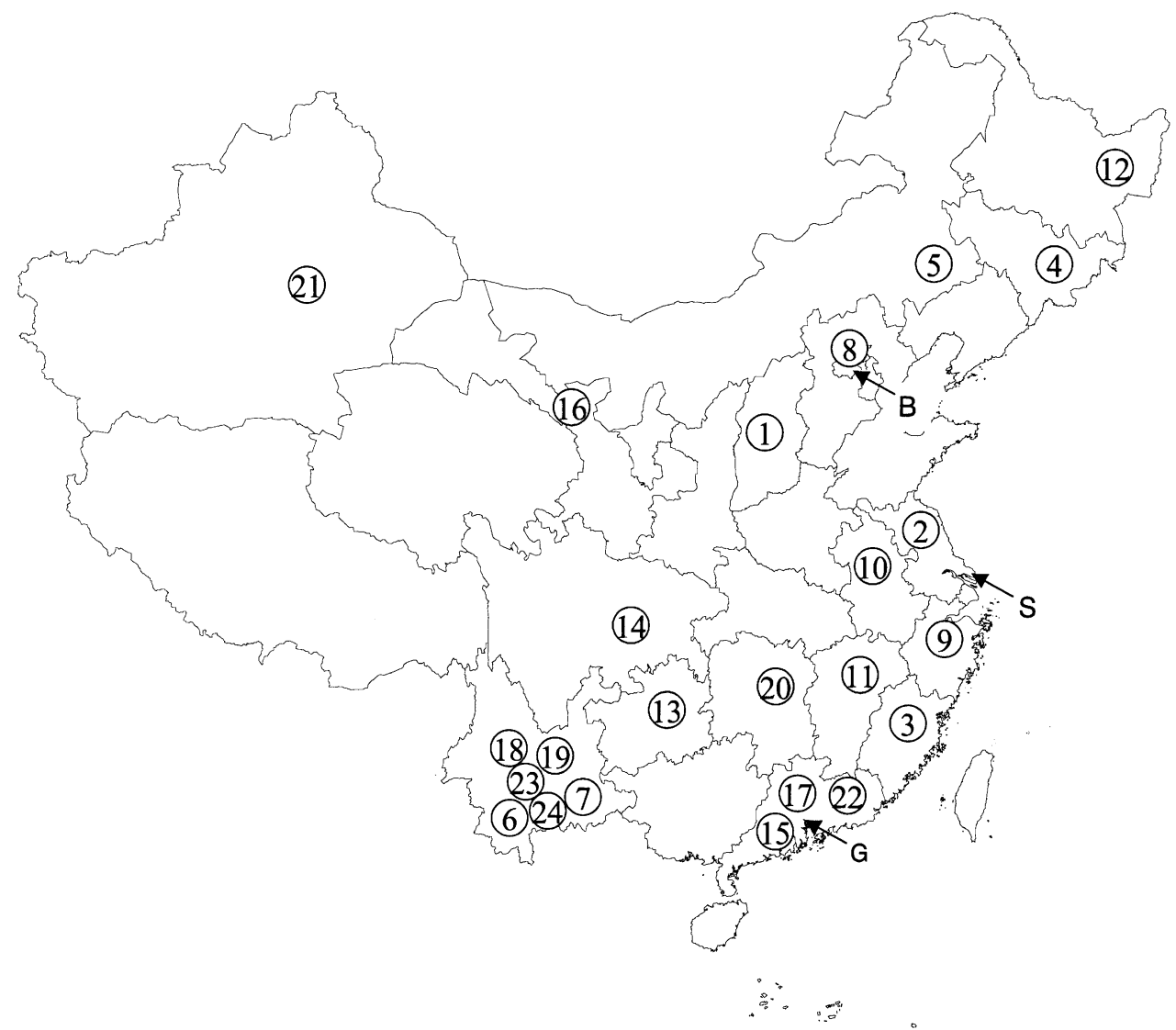

Figure 1. Locations of the sites in China from which Varroa mites were collected. Numbers correspond to sample sites in Table II. Beijing, Shanghai and Guangzhou are indicated by the end of arrows of the letters $\mathrm{B}, \mathrm{S}$ and $\mathrm{G}$ respectively.

(Tab. II). Not all mites samples were sequenced because enzyme analysis was less costly and provided information on genotype also, although at a more crude level.

\section{RESULTS}

The identities of the mites collected, as determined from their mtDNA sequences or from restriction enzyme analyses, are summarized in Table II.

\subsection{Varroa mites collected from Apis mellifera}

In many of the samples, when conditions allowed, reproductive status of Varroa mites were determined in worker brood of Apis mellifera, and all were found capable of reproduction. MtDNA sequences obtained from all 17 Varroa samples collected from A. mellifera were identical to that of the Korean genotype of $V$. destructor described by Anderson and Trueman (2000) (GenBank accession number AF106899). Restriction enzyme analyses on varying numbers of mites from each location confirmed that mite samples from the different locations were invariant (see Fig. 2). Identification of mites was based on sequence data which showed that the mtDNA of the Korea genotype $V$. destructor has a Xho1 but not a Sac1 site, while the mtDNA of the Japan genotype of $V$. destructor has a Sac 1 but not a Xho 1 site while the mtDNAs of the China and China 2 genotypes of $V$. destructor have both a Sac 1 


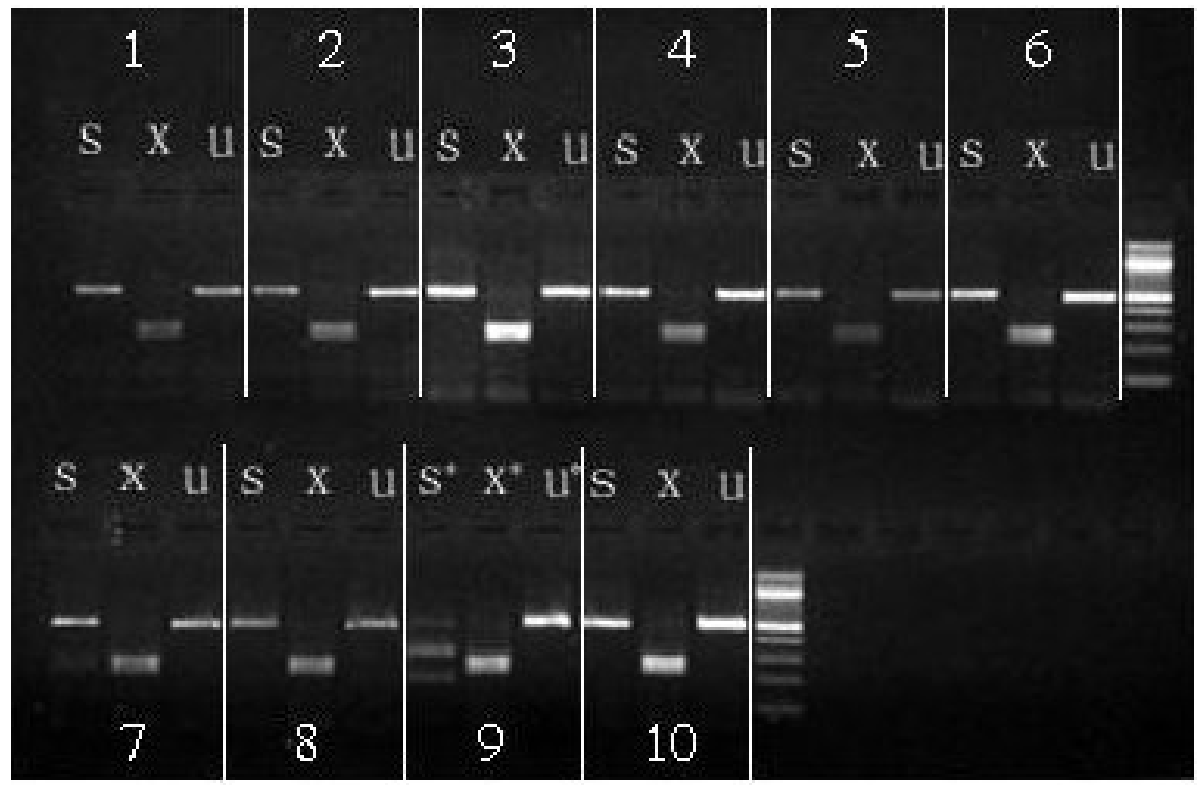

Figure 2. A representative gel of a restriction enzyme analysis carried out on Varroa mite isolates from China. Each of the 10 samples has been treated with the Sac1 enzyme (S), the Xho1 enzyme (X) or untreated (U). The wells to the right of Samples 6 and 10 contained molecular size markers. All the samples, except sample 9, were only cut with Xho1 and hence are the Korea genotype of V. destructor. Sample 9 (marked as $\mathrm{S}^{*} \mathrm{X}^{*} \mathrm{U}^{*}$ ) has been cut with both $\operatorname{Sac} 1$ and $\mathrm{Xho1}$ and hence is either the China or China 2 genotype of V. destructor.

and a Xho1 site. Mite samples collected from bottom boards (after knockdown by acaricides) showed similar DNA yield and quality compared to those collected live from the brood cells.

\subsection{Varroa mites collected from Apis cerana}

None of the Varroa mite samples were observed to reproduce on worker brood in Apis cerana. MtDNA sequences obtained from Varroa mites collected from A. cerana colonies at 2 different locations in Guangdong Province were identical to that of the China genotype of $V$. destructor described by Anderson and Trueman (2000) (GenBank accession number AF106900).

MtDNA sequences obtained from Varroa mites collected from five A. cerana colonies at Mongzi County, Yunnan Province, and from A. cerana colonies in three apiaries at Dayao County, Yunnan Province, were identical to each other but different from any previously recorded genotype. The mtDNA sequences of these mites were similar to that of the China genotype described by Anderson and Trueman (2000) but differed from that sequence by four base pairs. As this is the second Varroa genotype to be found on A. cerana in China we assign it as the China 2 genotype (or haplotype) of $V$. destructor. Its mtDNA sequence has been placed in the GenBank database under the accession number AY372063. The sequence is compared with that of the original China genotype of $V$. destructor in Figure 3.

The mtDNA sequences of mites collected from A. cerana colonies in four apiaries at Xishuangbanna, Yunnan Province, were identical to those of the Vietnam genotype of $V$. destructor, described by Anderson and Trueman (2000).

Again, restriction enzyme analyses on varying numbers of mites from each location confirmed that mite samples from the different locations were invariant (Fig. 2). 
1 ATTTATTTTGATTTTTTGGACACCCAGAaGTTTATATTTTAATTTTGCCT 50 China ||||||||||||||||||||||||||||||||||||||||||||||||||

1 ATTTATTTTGATTTTTTGGACACCCAGAAGTTTATATTTTAATTTTGCCT 50 China 2

51 GGTTTTGGTATTATTTCTCATGTAATTTGTATACAgAgAGGGAagAagCA 100 China |||||||||||||||||||||||||||||||||||||||||||||| $\mid$

51 GGTTTTGGTATTATTTCTCATGTAATTTGTATACAAAGAGGAAGAAGCA 100 China 2

101 GCCTTTTGGAAATTTAgGGATAATTTACGCTATAATAACTATTGgTATTT 150 China ||||||||||||||||||||||||||||||||||||||||||||||

101 GCCTTTTGGAAATTTAGGGATAATTTACGCTATAATAACTATCGGTATTT 150

China 2

151 TAGGTTTTATTGTATGAGCTCATCATATATTTACAGTAGGAATAGATATT 200 ||||||||||||||||||||||||||||||||||||||||||||||

151 TAGgTTTTATTGTATGAGCTCATCATATATTTACAGTAGGAATAGATATT 200

China

China 2

201 GATACTCGAGCATATTTTACTGCAGCTACAATAATTATTGCGGTTCCTAC 250 |||||||||||||||||||||||||||||||||||||||||||||||

201 GATACTCGAGCATATTTTACTGCAGCTACAATAATTATTGCGGTTCCTAC 250

China

China 2

251 TGGTATTAAAATTTTTTCTTGATTAGCAACAATTCATGGTTCTATAGTTA 300

China

|||||||||||||||||||||||||||||||||||||||||||||||||

251 TGGTATTAAAATTTTTTCTTGATTAGCAACAATTCATGGTTCTATAGTTA 300

China 2

301 AATTAGATGTCCCAATAATTTGATCTTTAGGTTTTATTTTTTTATTTACT 350

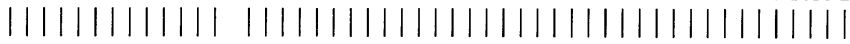

301 AATTAGATGTCCCGATAATTTGATCTTTAGGTTTTATTTTTTTATTTACT 350

China

China 2

351 TTAGgGGGTATTACTGGTGTAATTTTAGCTAATTCTTCTATTGATATTGT 400 |||||||||||||||||||||||||||||||||||||||||||||||||||||||

China

China 2

401 TTTACATGATACTTATTATGTAGTAGCACATTTTCACTATGTATTAAGAA 450

China ||||||||||||||||||||||||||||||||||||||||||||

401 TTTACATGATACTTATTATGTAGTAGCGCATTTTCACTATGTATTAAGAA 450

China 2

451 TAGGGGCT 458

|| || ||||

451 TAGGGGCT 458

China

China 2

Figure 3. MtDNA sequences of the original China genotype of $V$. destructor and the China 2 genotype of $V$. destructor. Differences in base-pairs are highlighted in bold and by a gap.

\section{DISCUSSION}

Our results have helped clarify the taxonomic status of Varroa mites infesting European and Asian honey bees in China.
Among the Varroa mites we examined from A. mellifera, only one mite genotype, the Korea genotype of $V$. destructor, was detected. This result confirms a similar finding by Anderson and Trueman (2000). We did not detect the 
Japan genotype of $V$. destructor nor any genotypes of $V$. jacobsoni. Because we and previous researchers have failed to find the Korea genotype of $V$. destructor on A. cerana in China, which hosts its own particular genotypes, it is almost certain that the Korea genotype was introduced to China on A. mellifera, probably shortly before 1957 when Varroa were first noticed causing problems to A. mellifera (Chen, 1993).

In our studies, we detected three different Varroa genotypes on A. cerana in China; the China and Vietnam genotypes of $V$. destructor, and a new genotype which we named the China 2 genotype of $V$. destructor. Our detection of the China genotype from two locations in Guangdong Province confirms the first report of this mite in Guangdong Province, at Guangzhou in 1996, by Anderson and Trueman (2000). Prior to our study, the Vietnam genotype of $V$. destructor had been found on A. cerana in Vietnam in 1996 (Anderson and Trueman, 2000), and then in 2002 on A. cerana in Thailand (Warrit and Smith, unpublished data). Our detection of this genotype at Xishuangbanna, Yunnan Province, which lies to the north of Vietnam, further extends its geographical range past the official borders of Vietnam.

Our results suggest that there is natural genetic isolation between the different Varroa genotypes infesting A. cerana and A. mellifera colonies in China. If this were not the case, then the different genotypes in China should be readily found on either bee. Clearly, we found that this was not the case. Natural genetic isolation between sympatric populations of different Varroa genotypes (those infesting A. mellifera and those infesting $A$. cerana) has now been reported from many locations in Asia (Anderson and Trueman, 2000; Fuchs et al., 2000) with the best studied example being in Java, Indonesia. There, the introduced A. mellifera are infested with the introduced Korea genotype of $V$. destructor and the native $A$. cerana are infested with the Java genotype of V. jacobsoni (Anderson and Sukarsih, 1996). Genetic separation between the two mite genotypes is partly maintained by the inability of the Java genotype of $V$. jacobsoni to reproduce on A. mellifera (Anderson, 1994; Anderson and Trueman, 2000), while the introduced Korea genotype of $V$. destructor has never been detected in the A. cerana colonies (Anderson and Trueman, 2000). The reasons for the lack of 'drift' of the Korea genotype are unclear but may reflect a more vigorous grooming response of the A. cerana to a foreign (and physically larger) mite genotype (the Korea genotype of $V$. destructor), as suggested by Peng et al. (1987). Further studies on the mechanism responsible for maintaining genetic isolation between sympatric Varroa genotypes in Asia would be useful because its determination could lead to the development of new control methods for the Varroa genotypes that are so destructive to A. mellifera.

In previous studies aimed at identifying Varroa mites from their DNA sequences, mites have been collected live and preserved immediately in $70 \%$ alcohol. This collection method, while ensuring that the mite DNA is not damaged, is time consuming, because many capped bee brood cells need to be opened in order to find live mites. To find an easier collection method, we collected some dead mites from the bottom boards of some hives within 24 hours following the application of miticide, placed them immediately into $70 \%$ alcohol and then treated them similarly to those mites that had been collected live. We experienced no difficulties in obtaining DNA from mites collected this way nor in determining their identification from PCR amplified DNA. This collection method will therefore be useful in future studies.

\section{ACKNOWLEDGMENTS}

We thank the numerous friends and colleagues who helped us collect mites and those who sent us mites for analysis, especially Zhili Yan, Zhengzhi Liang, Shuigen Lin, Chonggao Chen, Xiangsheng Dao and Zuncheng Lin. Ms Kerrie Medveczky and Ms Fiona Spier of CSIRO Entomology, Canberra, Australia, provided excellent assistance. This study was financially supported by grants from US Department of Agriculture (Scientific Cooperation Program) and The National Natural Science Foundation of China. We thank three anonymous reviewers and $\mathrm{S}$. Fuchs for comments that improved this manuscript.

Résumé - Identification des acariens Varroa (Acari : Varroidae), parasites d'Apis cerana et d'Apis mellifera en Chine. On connaît très peu de choses concernant le statut taxonomique des acariens Varroa qui infestent les abeilles domestiques européennes introduites (Apis mellifera L.) et les 
abeilles asiatiques indigènes (Apis cerana Fabricius) en Chine. Dans cet article nous résumons d'abord l'état actuel des génotypes connus de Varroa destructor Anderson and Trueman et de V. jacobsoni Oudemans (Tab. I), puis nous donnons les résultat d'une étude pour laquelle nous avons prélevé 24 échantillons d'acariens Varroa dans 17 régions de Chine (Fig. 1 ; Tab. II) et utilisé le séquençage de l'ADN conjointement avec des digestions par des enzymes de restriction (Fig. 2) afin d'identifier les acariens qui infestent en Chine les deux espèces d'abeilles.

Tous les acariens prélevés dans les colonies d'A. mellifera ont été identifiés comme étant du génotype coréen de $V$. destructor, ce qui confirme les résultats similaires obtenus dans des études antérieures. Les acariens prélevés dans des colonies d'A. cerana dans deux localités de la province de Guangdong étaient du génotype chinois de $V$. destructor, confirmant aussi les résultats d'études antérieures. Les acariens prélevés dans les colonies d'A. cerana dans trois ruchers du comté de Dayao, province de Yunnan et dans cinq colonies du comté de Mongzi, province de Yunnan appartenaient à un nouveau génotype de $V$. destructor, que nous avons nommé génotype chinois 2 (Fig. 3). Les acariens prélevés dans les colonies d'A. cerana dans quatre ruchers à Xishuangbanna, province de Yunnan, région située au nord du Vietnam, étaient du génotype vietnamien de $V$. destructor, ce qui étend la zone de répartition géographique de cet acarien.

Nos résultats sont applicables aux futurs efforts de lutte contre cet acarien et de mise en quarantaine des abeilles en Chine. Nous avons montré que $V$. jacobsoni n'est pas présent en Chine et que les acariens Varroa qui infestent $A$. mellifera appartiennent à un seul génotype (le génotype coréen de $V$. destructor), génotype qui parasite $A$. mellifera dans la plupart des régions du globe. Ce génotype a été probablement introduit pour la première fois en Chine dans les années 1900 à la suite d'importation d'A. mellifera. Nos études montrent aussi qu'il existe un isolement génétique naturel entre les génotypes de Varroa qui infestent $A$. cerana et $A$. mellifera, phénomène qui a été mentionné maintenant dans de nombreux autres endroits d'Asie.

Apis mellifera / Apis cerana / Varroa spp. / génotype chinois 2 / génétique populations

\footnotetext{
Zusammenfassung - Identifikation von Varroa Milben auf Apis cerana und Apis mellifera in China (Acari: Varroidae). Über den taxonomischen Status der Varroa Milben (Acari: Varroidae), die die nach China eingeführten Völker der europäischen Honigbienen sowie die einheimischen asiatischen Honigbienen (Apis cerana F.) befallen, ist wenig bekannt. In diesem ersten Artikel fassen wir zunächst den derzeitigen Stand der bekannten Genotypen von Varroa destructor und V.jacobsoni zusammen (Tab. I) und berichten dann über die
}

Ergebnisse einer Studie, in der wir 24 Proben von Varroamilben von den 2 Bienenarten aus 17 Provinzen über ganz China gesammelt (Abb. 1, Tab. II) und mit DNA-Sequenzierung in Verbindung mit Restriktionsenzymverdauung (Abb. 2) identifiziert haben.

Alle von A. mellifera Völkern stammenden Milben wurden als der koreanische Genotyp von Varroa destructor Anderson und Trueman bestimmt. Die von $A$. cerana Völkern an zwei verschiedenen Orten in der Guangdong Provinz gesammelten Milben waren der chinesische Genotyp von $V$. destructor. Dies bestätigte die Ergebnisse von früheren Studien. Die aus $A$. cerana Völkern in 3 Bienenständen in Dayao County, Yunnan Provinz, und von 5 Völkern in Mongzi County, Yunnan Provinz gesammelten Milben waren ein neuer Genotyp, den wir den China 2 Genotyp (Abb. 3) von $V$. destructor nannten. Die aus $A$. cerana Völkern von 4 Bienenständen in dem nördlich von Vietnam gelegenen Xishuangbanna, Yunnan Provinz, gesammelten Milben waren der vietnamesische Genotyp von $V$. destructor, wodurch das geographische Verbreitungsgebiet dieser Milbe erweitert wird.

Unsere Ergebnisse sind für die zukünftige Milbenbekämpfung und Quarantäne-Bemühungen in China von Bedeutung. Wir haben gezeigt, dass $V$. jacobsoni nicht in China vorkommt, und dass die zur Zeit die A. mellifera Völker in China befallenden Milben einem einzigen Genotyp, dem koreanische Genotyp von $V$. destructor angehören, dem gleichen $\operatorname{der}$ A. mellifera in den meisten Ländern der Welt befällt. Dieser Genotyp wurde vermutlich erstmalig im 20. Jahrhundert mit nach China importierten $A$. mellifera Völkern eingeführt. Unsere Studien weisen darüber hinaus darauf hin, dass zwischen A. cerana und A. mellifera infizierenden Milben eine natürliche Isolation besteht. Über diese Erscheinung ist bereits aus vielen anderen Orten in Asien berichtet worden.

Apis mellifera / Apis cerana / China 2 Genotyp von Varroa destructor / Varroa spp.

\section{REFERENCES}

Akratanakul P., Burgett M. (1975) Varroa jacobsoni: a prospective pest of honeybees in many parts of the world, Bee World 56, 119-121.

Anderson D.L. (1994) Non-reproduction of Varroa jacobsoni in Apis mellifera colonies in Papua New Guinea and Indonesia, Apidologie 25, 412-421.

Anderson D.L. (2000) Variation in the parasitic bee mite Varroa jacobsoni Oud., Apidologie 31, 281292.

Anderson D.L., Fuchs S. (1998) Two genetically distinct populations of Varroa jacobsoni with contrasting reproductive abilities on Apis mellifera, J. Apic. Res. 37, 69-78. 
Anderson D.L., Sukarsih (1996) Changed Varroa jacobsoni reproduction in Apis mellifera colonies in Java, Apidologie 27, 461-466.

Anderson D.L., Trueman J.W.H. (2000) Varroajacobsoni (Acari: Varroidae) is more than one species, Exp. Appl. Acarol. 24, 165-189.

Anderson D.L., Gibbs A.J., Gibson N.L. (1998) Identification and phylogeny of spore-cyst fungi (Ascosphaera spp.) using ribosomal DNA sequences, Mycol. Res. 102, 541-547.

Anderson D.L., Halliday R.B., Otis G.W. (1997) The occurrence of Varroa underwoodi (Acarina: Varroidae) in Papua New Guinea and Indonesia, Apidologie 28, 143-147.

Chen Y. (1993) Honeybee diseases and their prevention and control, in: Chen Y., Li Z., Qiu Z., Qiao Y., Yan H., Jin Z., Wang S., Wang Y., Qiu J., Huang W. (Eds), Apiculture in China, Agric. Pub. House, Beijing, China, pp. 52-59.

De Guzman L.I., Delfinado-Baker M. (1996) A new species of Varroa (Acari: Varroidae) associated with Apis koschevnikovi (Apidae: Hymenoptera) in Borneo, Int. J. Acarol. 22, 23-27.

Delaplane K.S. (2001) Varroa destructor, revolution in the making, Bee World 82, 157-159.

Delfinado-Baker M., Aggarwal K. (1987) A new Varroa (Acari: Varroidae) from the nests of Apis cerana (Apidae), Int. J. Acarol. 13, 233-237.

Fuchs S., Long L.T., Anderson D.L. (2000) A scientific note on the genetic distinctness of Varroa mites on Apis mellifera L. and on Apis cerana Fabr. in North Vietnam, Apidologie 31, 459-460.

Garridoa C., Rosenkranza P., Paxtonb R.J., Gonçalvesc L.S. (2003) Temporal changes in Var- roa destructor fertility and haplotype in Brazil, Apidologie 34, 535-541.

Koeniger N., Koeniger G., Delfinado-Baker M. (1983) Observations on mites of the Asian honey bee species, Apidologie 14, 197-204.

Koeniger N., Koeniger G., Wijayagunasekera N.H.P. (1981) Observations on the adaptation of Varroa jacobsoni to its natural host Apis cerana in Sri Lanka, Apidologie 12, 37-40.

Koeniger G., Koeniger N., Anderson D.L., Lekprayoon C., Tingek S. (2002) Mites from debris and sealed brood cells of Apis dorsata colonies in Sabah (Borneo) Malaysia, including a new haplotype of Varroa jacobsoni, Apidologie $33,15-24$.

Oudemans A.C. (1904) Note VIII. On a new genus and species of parasitic acari, Notes Leyden Mus. 24, 216-222.

Peng C.Y.S., Fang Y.Z., Xu S.Y., Ge L.S. (1987) The resistance mechanism of the Asian honey bee Apis cerana Fabr. to an ectoparasitic mite, Varroa jacobsoni Oudemans, J. Invertebr. Pathol. 49, 5460 .

Rath W. (1999) Co-adaptation of Apis cerana Fabr., and Varroa jacobsoni Oud., Apidologie 30, 97 110 .

Woo K.S. (1992) New honeybee mite Varroa underwoodi on Apis cerana in South Korea, Honeybee Sci. 13, 173-174 (in Japanese).

Zhang Z. (2000). Notes on Varroa destructor (Acari: Varroidae) parasitic on honeybees in New Zealand, Syst. Appl. Acarol. (Special Publications) 5, 9-14. 